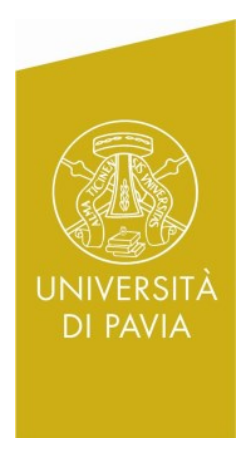

Department of Economics and Management DEM Working Paper Series

\title{
The Overshooting of Firms Destruction, Banks and Productivity Shocks
}

Lorenza Rossi

(Università di Pavia)

\# 147 (01-18)

Via San Felice, 5

I-27100 Pavia

economiaweb.unipv.it

January 2018 


\title{
The Overshooting of Firms Destruction, Banks and Productivity Shocks
}

\section{Lorenza Rossi ${ }^{1}$}

\section{December 2017}

\begin{abstract}
Using U.S. quarterly data we show that in response to a positive productivity shock: i) firms' creation increases ii) firms' destruction reduces at impact, it then overshoots its long run level, peaking three years later above its steady state. iii) banks' markup reduces. To address these three facts, we provide an NK-DSGE model where firms dynamics is endogenous, the banking sector is monopolistic competitive and defaulting firms do not repay loans to banks. We show that the interaction between firms and banks is key to replicate the empirical evidence. Contrary to the conventional wisdom, in the baseline model the effects of the shock are dampened with respect to a model without banks.

KEYWORDS: firms creation, firms destruction, monopolistic banks, countercyclical banks' markup, productivity shocks, overshooting of firms destruction, BVAR.

JEL codes: E32; E44; E52; E58

\footnotetext{
${ }^{1}$ Department of Economics and Management, University of Pavia, via San Felice, 5. 27100 - Pavia. Phone: +390382 986483. Email: lorenza.rossi@unipv.it.

The author thanks Guido Ascari, Barbara Annicchiarico, Henrique Basso, Alessandra Bonfiglioli, Paolo Bonomolo, Pablo Burriel, Andrea Caggese, Efrem Castelnuovo, Lilia Cavallari, Jim Costain, Davide De Bortoli, Federico Etro, Martin Ellison, Stefano Fasani, Luca Fornaro, Jordi Galì, Fabio Ghironi, Giovanni Pellegrino, Carlos Thomas and Lauri Vilmi, for their helpful comments and suggestions. I am grateful to all the participants to: the CEF Conference 2016 (Bordeaux), the 2014 X Dynare Conference (Bank of France), the Workshop on: "Macroeconomics, Financial Frictions and Asset Prices" - University of Pavia. I especially thank the seminar participants at: CREI (University of Pompeu Fabra), the Institute for Economic Analysis (Universitat Autonoma de Barcelona), the Bank of Spain, CEIS (University of Tor Vergata) seminar, CRENOS (University of Sassari) and LUISS Guido Carli. This work is supported by the EU 7th framework collaborative project "Integrated Macro-Financial Modelling for Robust Policy Design (MACFINROBODS)" grant no. 612796. All remaining errors are of my own.
} 


\section{Introduction}

This paper contributes to the literature of firms dynamics and the contribution is twofold. First, we estimate a BVAR and we provide evidence on the effects of an expansionary productivity shock on the dynamics of firms, both in terms of firms' creation and destruction. We show that in response to a positive productivity shock firms creation increases, while firms destruction decreases at impact. Importantly, after few periods a positive productivity shock produces a long-lasting increase in firms' destruction that overshoots its long run level, peaking three years later above its steady state. After seven years the variable is almost back to its steady state. Besides this, we find that a positive productivity shock is followed by a decrease of the bank markup.

The second contribution of this paper is to provide a model capable to reproduce these empirical facts. We build up a New-Keynesian Dynamic Stochastic General Equilibrium model - henceforth, NK-DSGE model - characterized by firms' endogenous entry and exit decisions, ${ }^{2}$ together with an imperfect competitive banking sector which provides loans to firms. Further, we assume that banks cannot insure against the risk of firms' default and thus they incur in balance sheet losses every time firms exit the market without repaying the loan. This assumption makes the banks' markup endogenous and countercyclical. ${ }^{3}$

We model firms' destruction using a modified version of the mechanism proposed by Melitz (2003) and Ghironi and Melitz (2005) for exporting firms. In particular, we assume that firms decide to produce as long as their specific productivity is above a cut-off level, which is determined by the level of productivity that makes firms' profits equal to zero.

In this context, we study the dynamics of the model in response to a positive productivity shock. The main results can be summarized as follows. First, in response to positive productivity shocks firms' profits opportunities increase and households invest in new firms. Thus, as in our BVAR analysis

\footnotetext{
${ }^{2}$ In the remainder of this paper we will use the expression "firms' destruction (creation), firms exit (entry) and firms' deaths (births) as synonymous.

${ }^{3}$ Rousseas (1985), among others, was the first to claim that banks desire to increase their markup to restore their profits, every time they fear a fall in the economic activity, followed by firms defaults and losses in their balance sheets.

In this paper we are interested to capture the relationship between firms' default and the banks' markup. For this reason, to leave the model as simple as possible, we do not consider any other variable that may affect the dynamics of the bank markup.
} 
firms creation increases. Total output increases as well and the economy enters into a boom. At the same time the probability of firms' default fall down and firms' destruction decreases, thus being countercyclical at impact. A direct consequence of this fact is that the propagation mechanism of productivity shocks, via the extensive margin of the good-market, is stronger than in a model with exogenous exit, as for example in the seminal paper of Bilbiie, Ghironi and Melitz (2012) - henceforth, BGM (2012). In their framework, the probability of firms' default is constant. This assumption implies that the number of firms exiting the market is mildly procyclical, i.e. firms destruction increases in booms and decreases in downturns, thus being at odds with the data. ${ }^{4}$

Importantly, and consistently with our BVAR analysis, after three periods from the initial drop firms' destruction overshoots persistently it long run level, so that after seven years firms destruction is almost back to its long-run level. The overshooting of firms destruction can be explained as follows. When the economy is hit by a positive aggregate productivity shock, firms profits increase and the cut-off level of firms-specific productivity that makes profits equal to zero decreases, thus reducing the probability of firms' default. This not only affects firms' exit decisions, but also firms' decision to enter the market. In fact, the lower the probability of firms default the higher are expected average profits of new entrants and the higher is firms creation. Further, as in Ghironi and Melitz (2005) new entrants draw their specific productivity only upon entrance. This induce a large increase in business creation in response to a productivity shock, since both firms with low and high level of productivity enter in boom. ${ }^{5}$ However, those new entrants drawing a productivity lower than the cut-off are immediately separated, before they start producing. As soon as the aggregate productivity reverts to its lower long-run values, also the incumbent firms with a low productivity exit the market. Both these effects are responsible for the overshooting of firms destruction. Remarkably, in our model the counter-

\footnotetext{
${ }^{4}$ The reason is the following. Suppose that a positive technology shock hits the economy. New firms enter the market and the total number of firms increases. If the exit probability is constant and firms' destruction is proportional to the total number of firms, firms' destruction increases during a boom instead of decreasing and decreases during a recession.

${ }^{5}$ Even though this assumption seems not realistic it helps to match the empirical fact that also firms with a very low level of productivity enter the market during a boom, being then separated in few periods. See for example Bartelsman, Haltiwanger, and Scarpetta (2004)
} 
cyclicality of firms destruction generates an endogenous and countercyclical banks' markup. This is due to the facts that defaulting firms do not repay loans to banks. Consequently, banks endogenously increase their markup to restore their profits every time they fear a fall in the economic activity, followed by firms defaults and losses in their balance sheets.

Finally, we compare the result of our baseline model with a model without banks, where firms self finance their activity. We find that, in this model the overshooting of firms destruction is larger than in the baseline model and that, contrary to the conventional wisdom, the effect of the shock are amplified in the model without banks. Furthermore, the implied IRFs of our baseline model are more in line with the empirical ones, than the IRFs generated by the model without banks. This confirms that embodying financial intermediaries in the DSGE model helps to replicate the empirical facts.

The remainder of the paper is organized as follows. Section 2 briefly discusses the related literature and clarify the contribution of our paper. Section 3 provides an empirical motivation by reporting the dynamic responses of the US establishments births and deaths, as well as of a proxy of the US banks' markup, to a positive productivity shock. Section 4 spells out the model economy, while Section 5 contains the main results of the model. It also compares the performance of the IRFs obtained in calibrated model with the IRFs generated by a BVAR estimated using data simulated by our baseline model. Section 6 presents some sensibility analysis. Section 7 concludes, while technical details are left in the Technical Appendix.

\section{Related Literature}

A growing number of papers discuss the impact of firms' dynamics on business cycle. In the DSGE literature the seminal paper of BGM (2012) considers a model with endogenous firms entry and shows that the sluggish response of the number of producers (due to the sunk entry costs) generates a new and potentially important endogenous propagation mechanism for real business cycle models. Similarly, Etro and Colciago (2010) study a DSGE model with endogenous good market structure under oligopolistic competition and show that their model improves the ability of a flexible price model in matching impulse response functions for US data. Colciago and Rossi (2015a and 2015b) extend this model accounting for search and matching 
frictions in the labor market. ${ }^{6}$ Shao and Silos (2014) investigate the cyclical dynamics of the value of a vacant position in labor markets characterized by search and matching frictions and firms endogenous entry. Remarkably, Bilbiie, Ghironi and Fujiwara (2014) study optimal monetary policy in the $\operatorname{BGM}(2012)$ framework and show that deviations from long-run price stability are optimal in a model with endogenous firms' entry and product variety. Colciago (2015) studies optimal taxation in a model with endogenous firms entry and oligopolistic competition, showing that optimal dividend taxation depends on the form of competition and on the nature of firms sunk entry costs. Several papers, also provide empirical evidence that the number of producers varies over the business cycle and that firms dynamics may play an important role in explaining business cycle dynamics and statistics. ${ }^{7}$ Further, using an open economy framework, Ghironi and Melitz (2005 and 2007) study the role of firms dynamics on international trade, whereas Bergin and Corsetti (2008) and Cavallari (2013) analyze the role of monetary policy and international coordination in a model with endogenous firms' entry.

Despite these recent advances in improving the performance of the DSGE models, all these papers consider an exogenous and constant probability of firms default. Furthermore, all these papers consider a perfect financial market and do not analyze the interaction between firms' destruction and financial markets. This paper try to shed some light on this relationship by considering a model with endogenous firms creation and destruction together with an inefficient banking sector interacting with firms. The starting points to build up our theoretical model are the three stylized facts mentioned in the introduction: i.e., i) the procyclicality of firms' entry; ii) the countercyclicality of firms exit together with its overshooting and iii) the countercyclicality of the banks' markups.

The procyclicality of firms entry is well accepted by the empirical literature, whereas the cyclicality of firms' destruction is still an open issue. For example, Campbell (1998), using a sample of US manufacturing firms, finds a positive correlation between firms' entry rates and the growth rate of real GDP. He finds an even stronger but negative correlation between the

\footnotetext{
${ }^{6}$ They show that their model contributes to explain the volatility of the labor market variables and also stylized facts concerning the countercyclicality of price markups, the procyclicality of firms profits, the overshooting of the labor share of income and job creation by new firms. Shao and Silos (2014) get similar results on the dynamics of the labor share of income.

${ }^{7}$ Among others, Lewis and Poilly (2012), Lewis and Stevens (2015), Jaimovich and Floetotto (2008) and Colciago and Rossi (2015b).
} 
growth rate of real GDP and business' failures, implying that firms' destruction is countercyclical. Using a different dataset, Totzek (2009) and Vilmi (2011) show similar results. Instead, Broda and Weinstein (2010), show that product destruction is much less cyclical than product creation, at least at product level. Similar results are obtained by Lee and Mukoyama (2015), using US Census annual data at plant level. ${ }^{8}$ These papers consider the unconditional correlation between GDP growth and entry and exit rates, whereas very few studies concentrate on the conditional responses of firms dynamics and the real GDP. An example are Lewis (2009) and Etro and Colciago (2010), among others. Using Structural VAR techniques, they study the responses of firms' entry and the real GDP conditional to a TFP shock and find that entry is procyclical. We estimate a BVAR showing that in response to a productivity shock firms' entry is procyclical, whereas firms' destruction and banks' markup are countercyclical at impact. Importantly, we find that firms' destruction is characterized by countercyclicality and overshooting. We provide a model capable to replicate all these facts.

The countercyclicality of the banks markup - often computed using as a proxy the banks' loan spread - is found in several papers. Examples are Hannan and Berger (1991), Asea and Blomberg (1998) and more recently Lown and Morgan (2008), Nikitin and Smith (2009) and Kwan (2010). In particular, Kwan (2010) reported that the commercial and industrial loan rate spread has been of about 66 basis points higher (or $23 \%$ higher) than its long-term average in the aftermath of the recent financial crisis. Dueker and Thornton (1997), Angelini and Cetorelli (2003), and more recently, Olivero (2010) and Aliaga-Diaz and Olivero (2012), all show that banks' markup is countercyclical. However, they do not investigate the role of firms dynamics.

To the best of our knowledge few papers try to model firms' exit in a DSGE framework. Exceptions are Totzek (2009), Vilmii (2011), Cavallari (2015), Hamano and Zanetti (2015), Cesares and Poutineau (2014), Clementi and Palazzo (2016) and Asturias et al (2017). The closest to our paper are Totzek (2009), Cesares and Poutineau (2014) and Hamano and Zanetti (2015). First and foremost, they use different timing and a different exit condition. ${ }^{9}$ Second, their models are not based on the empirical evidence to

\footnotetext{
${ }^{8}$. BGM (2012) justify the assumption of exogenous exit on the base of these two studies, even though they also claim their choice is on the advantage of the model tractability.

${ }^{9}$ Totzek (2009) as well as Vilmi (2011) and Cesares and Poutineau (2014) assume that firms exit occurs at the end of the production period. Instead, in our model exit occurs before firms start producing. This implies that the average productivity changes along the
} 
a productivity shock. Thus, they do not focus on the overshooting of firms destruction in response to a positive productivity shock, neither theoretically nor empirically. Third, they consider a standard DSGE model with a perfect financial market.

Finally, few papers consider imperfect financial market together with firms dynamics. Bergin at al (2014) and La Croce and Rossi (2014) use a different framework to study the relationship between endogenous firms entry and financial imperfections. They show that entry contributes to the propagation of financial shocks. Both models consider endogenous business creation but exogenous firms destruction. Brand et al (2017) study the effect of an uncertainty shock in a model with search and monitoring costs in the credit market and firms dynamics. Finally, Cacciatore et al. (2015) and Shapiro and Epstein (2017) consider a model with endogenous firms creation and olipopolistics banks to study the effects of structural reforms.

\section{Empirical Motivation}

We now estimate a small BVAR and show the impulse responses to a positive productivity shock. In particular, using US quarterly data, we show the responses of the Establishments Births and Deaths together with a measure of the Banks' Markup, the real GDP and the CPI index. ${ }^{10}$ We consider two alternative and widely used measures of productivity: i) the quarterly series of measured labor productivity, labeled as LProd, which is also widely used

business cycle and, as will be discussed in the paper, it also implies a stronger response of output. Importantly, Cesares and Poutineau (2014) assume that the stochastic discount factor is not affected dynamically by the endogenous firms exit probability. This also implies that the exit probability does not affect firms' decision on entering the market as well as firms pricing decisions. Hamano and Zanetti (2015), focus on the importance of product turnover for aggregate fluctuations. Further, they consider a flexible price economy, whereas the final sector of our economy is characterized by sticky prices.

Clementi and Palazzo (2016) extend the analysis of Hopenhayn (1992) and find that entry and exit imply greater persistence and unconditional variation of aggregate timeseries. They also consider a perfect financial market and do not replicate the overshooting of firms destruction.

${ }^{10}$ As standard in the literature, we use the series of Establishments Births and Deaths as proxies of firms' creation and destruction. The series of Establishment births and deaths are downloaded from the Bureau of Labor Statistics (BLS). They are available only at establishment level. The BLS defines an establishment as: a single physical location where one predominant activity occurs. A firm is instead an establishment or a combination of establishments. 
in the literature ${ }^{11}$. ii) The quarterly TFP series based on growth accounting techniques proposed by Basu et al (2006), which is the Utilization Adjusted TFP series, ${ }^{12}$ labeled as TFP $u ;{ }^{13}$. The other series considered are: the CPI index and the real GDP, both downloaded from the FRED database. Finally, for the series of the Banks' Markup we follow the literature starting from Rousseas (1985) and we compute the bank markup as the spread between the US Bank Prime Loan Rate and the Fed Fund Rate. In particular, to tackle the issue of the unconventional monetary policy, for the policy rate we consider the Shadow Fed Fund Rate (SFFR), computed by Wu and Xia (2016). ${ }^{14}$ This is, in fact, considered a more appropriate measure of the policy rate in the VAR analysis done with samples including the ZLB. In the Appendix we show that our result on the dynamics of the Bank markup is robust to the use of the Effective Fed Fund Rate (EFFR) and of the Three Months Treasury Bills rate (TMTBR). We label the series used in the BVAR respectively as: $\operatorname{LProd}_{t},\left(T F P u_{t}\right), C P I_{t}, R G D P_{t}$, Births $_{t}$, Deaths $s_{t}$, Bmrkp $_{t}$. Given the short-time span available for the series of Establishments Deaths we estimate a BVAR using the sample: 1993Q2-2015Q1. ${ }^{15}$ The Bayesian approach to structural analysis has been considered for its versatility and capability to address the issue of short sample size. In fact, it avoids sampling errors in estimation of IRF bands that may occur when sample is short or, equivalently, when the model is highly over parameterized. ${ }^{16}$

The reduced form of the BVAR model is:

$$
Y_{t}=c+B_{1} Y_{t-1}+\ldots+B_{p} Y_{t-p}+\epsilon_{t}, \text { where }
$$

$Y_{t}=\left[\operatorname{LProd}_{t}\left(\right.\right.$ TFP $\left._{t}\right), C P I, R G D P$, Births, Deaths, Bmrkp $]$ is the vector

\footnotetext{
${ }^{11}$ Labor productivity, defined as Real Output Per Hour of All Persons in the Non-farm Business Sector (OPHNFB) has been dowloaded from FRED. The utilization adjusted $\mathrm{TFPu}$, can be downloaded, jointly with other related measures of productivity, from the websites of FED of S. Francisco.

${ }^{12}$ The importance of correcting for utilization effects in measured TFP has long been stressed in the literature (see, for example, Burnside et al. (1995) and references therein and Basu et al (2006)). Further, Chang and Hong (2006) argue in favour of using TFP growth instead of labour productivity as the latter is influenced by changes in the input $\operatorname{mix}$.

${ }^{13}$ Chang and Hong (2006) argue in favour of using TFP growth instead of labour productivity as the latter is influenced by changes in the input mix.

${ }^{14}$ The Bank Prime Loan Rate is available from FRED, while the shadow rate of the FED FUND is dowloaded from the Fed of Atlanta.

${ }^{15}$ Notice that also the BLS series of Establishments Births started only from 1992Q3.

${ }^{16}$ See Sims and Zha (1998).
} 
of the series used in the BVAR. $B_{j}(j=1,2, \ldots p)$ are $(N x N)$ autoregressive coefficient matrices, and $\epsilon_{t}$ is a white noise vector of the time series with $\epsilon_{t} \sim\left(0, \Sigma_{\epsilon}\right)$, and $\Sigma_{\epsilon}$ is the variance-covariance matrix. All the series, except for the banks markup, are expressed in logarithms of the levels. ${ }^{17}$

We estimate a BVAR(4) and for the prior distribution of the parameters we choose Minnesota Priors of 0.8 on the autoregressive coefficient of the first lag. These priors are justified by the short sample size. In fact, in this framework, it is assumed that the VAR residual variance-covariance matrix $\Sigma_{\epsilon}$ is known. In particular, here we use the entire variance-covariance matrix of the VAR system estimated by OLS. To verify the robustness of our results, the Appendix show the IRFs obtained using Normal Diffuse Priors. Also in this case we set the prior of the autoregressive coefficient of the first lag to 0.8 .

We choose a lower triangular Cholesky identification, ordering productivity first, such that on impact productivity shocks affect all the variables, while shocks to the other variables do not affect productivity at impact. The short-run identification strategy is motivated by two reasons. First, by the very short sample available, ${ }^{18}$ and second, by the type of the TFP shock considered in our theoretical model, which is persistent but temporary. ${ }^{19}$ The other series are ordered as indicated in the vector $Y_{t} .{ }^{20}$

The resulting IRFs under Minnesota priors, jointly with $16 \%$ and $84 \%$ credible bands, are plotted in Figure 1. It shows the IRFs in response to a one standard deviation labor productivity shock, while Figure 2 shows the same IRFs in response to a one standard deviation TFP shock. Notice that, the two BVAR models generate very similar IRFs. Indeed, in both models the CPI index decreases on impact, whereas the real GDP increases in response to the productivity shock. These patterns of RGDP and CPI suggest that such a shock generates IRFs that are in accordance with the

\footnotetext{
${ }^{17} \mathrm{As}$ it is now standard in the literature, this implicitly allows for the possible presence of cointegrating relations, without imposing restrictions on the longrun properties of the model, see Sims et al. (1990).

${ }^{18}$ We also consider a SVAR with short-run sign restrictions. The resulting IRFs are qualitatively similar and results are available upon request. We take the short-run Cholesky identification strategy as the baseline one because it relies on weaker restrictions.

${ }^{19}$ Adding a non-stationary productivity dynamics would highly complicate the aggregation techniques of our model with heterogenoeous firms, without changing qualitatively the results.

${ }^{20}$ The order of the five series follow the economic theory of our model. However, we have verified that changing the order of the variables does not affect the results.
} 
NK theory. Further, notice that in both models the series of establishments BIRTHS is procyclical and not particularly persistent, while the series of establishments DEATHS is countercyclical and overshoots its long run level for many periods. In particular, as shown in Figure 1, the series of establishments DEATHS is countercyclical at impact, it then shows an hump-shaped response, overshooting its long-run level after five quarters, and peaking at the twelfth quarter, that is after three years. Almost seven years after the initial drop the series is back to its steady state value. Finally notice that the bank markup is countercyclical and highly persistent. The Appendix, at the end of the paper, shows some robustness analysis. First, Figure 1A shows the responses obtained by estimating the VAR using the utility adjusted TFP. Notice, that the variables show similar patterns, however all the responses are more inertial in response to a TFP shock.

Figures 2A-3A, show the responses obtained with the two alternatives measure of productivity under Normal Diffuse priors. Notice that, all the responses show almost identical patterns. Finally, Figures 4A and 5A show the responses of a BVAR estimated using two alternative proxies of the bank markup: i) the spread between the Prime Loan Rate and the EFFR and the spread between the Prime Loan Rate and the TMTBR. Also using these alternative proxies, the bank markup is countercyclical. Notice however that, when the markup is computed with respect to the TMTBR it is less inertial and slightly overshoots its long-run level.

With these facts in mind, the next Section built up an NK-DSGE model able to replicate these empirical findings, at least qualitatively. Finally, in Section 5.1.3 we conduct and exercise by simulating data with our model. We then estimate a BVAR on such simulated data using the same Choleskyidentification strategy employed with US data. We show that the BVAR with simulated data returns impulse responses that well replicate those produced by the DSGE model. This suggests that our identification strategy can recover the true macroeconomic effects of a positive productivity shock. 

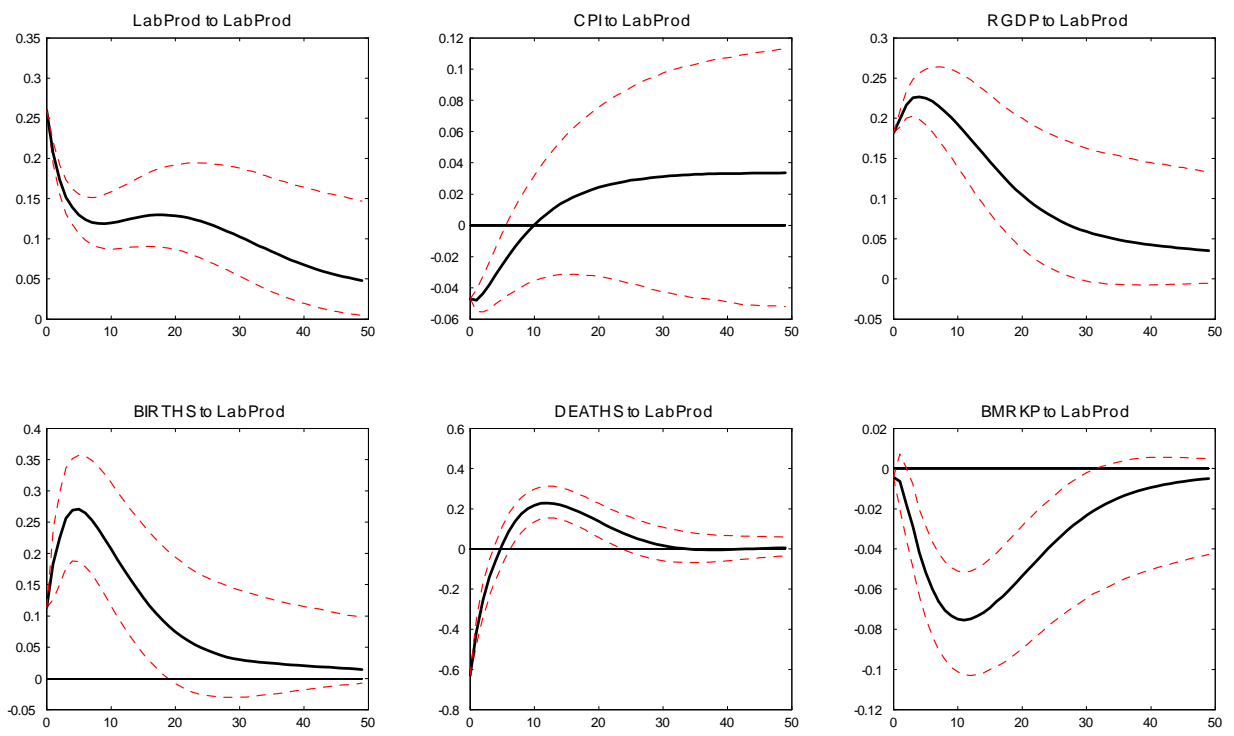

Figure 1. IRFs to a 1 standard deviation labor productivity shock.

Minnesota Priors

\section{The Model}

The model considered is a closed economy composed by four agents: households, firms, banks and the monetary authority which is responsible for setting the policy interest rate.

\subsection{Firms}

The supply side of the economy is composed by: i) the intermediate goodproducing firms equally distributed into a continuum of $k \in(0,1)$ symmetric sectors. Each sector produces a continuum of differentiated goods $i \in N$ under monopolistic competition and flexible prices ii) The retail sector is composed by $j=k$ firms, competing under monopolistic competition. Each firm purchases all goods produced by the sector $k$, bundles it using a CES technology and set prices à la Rotemberg (1982). ${ }^{21}$

\footnotetext{
${ }^{21}$ The retail sector is introduced only to separate the sticky price problem from that of firms dynamics.
} 


\subsubsection{Firms: the Intermediate Sectors}

Each sector $k$ produces a continuum of differentiated intermediate goods $i \in$ $N$, where $N$ represents the mass of available goods produced by the sector. For the sake of simplicity, we assume one-to-one identification between a product and a firm. Firm $i$ in sector $k$ enjoys market power and set prices $P_{i, k, t}$ as a markup over its marginal costs. Since all sectors are identical we consider a representative intermediate sector and we remove the index $k$. In this context, the production function of firm $i$ is,

$$
y_{i, t}=A_{t} z_{i, t} l_{i, t}
$$

where $l_{i, t}$ is the amount of labor hours employed by firm $i$, while $z_{i, t}$ is a firm specific productivity, which is assumed to be Pareto distributed across firms, as in Ghironi and Melitz (2005). The variable $A_{t}$ is instead an aggregate $\mathrm{AR}(1)$ productivity shock of the form:

$$
\ln \left(A_{t} / A\right)=\rho_{a} \ln \left(A_{t-1} / A\right)+\sigma_{a} u_{t}^{a},
$$

where $A$ is the steady state value of $A_{t}$ and where the innovation $u_{t}^{a}$ is a standard normal process with zero mean and a standard deviation equal to $\sigma_{a}$.

The intermediate-goods producing firm $i$ chooses the optimal price $P_{i, t}$ under monopolistic competition and flexible prices.It then maximizes its expected real profits solving the following problem:

$$
\begin{aligned}
& \max E_{0} \sum_{t=0}^{\infty} \Lambda_{0, t} j_{i, t}, \\
& \text { s.t. } \\
y_{i, t}= & A_{t} z_{i} l_{i, t}
\end{aligned}
$$

where $j_{i, t}$ are firm $i$ real profits, $\Lambda_{0, t}$ is the real stochastic discount factor, that will be defined below. The demand for the produced good $y_{i, t}$ comes from the retail sector and it is given by $y_{i, t}=\left(\frac{P_{i, t}}{P_{t}^{I}}\right)^{-\theta} y_{t}^{R}(k)$, where $y_{t}^{R}(k)$ is the aggregate demand of the retail firm $k$, with $P_{t}^{I}$ being the Price Index of the intermediate sector and $\theta$ being the elasticity of substitution among intermediate goods of the same sector. Real profits, $j_{i, t}$ are given by:

$$
j_{i, t}=\frac{P_{i, t}^{I}}{P_{t}} y_{i, t}-f^{F}+b_{i, t}-w_{t} l_{i, t}-\left(1+r_{t}^{b}\right) b_{i, t},
$$


where $\frac{P_{i, t}^{I}}{P_{t}} y_{i, t}$ are total real revenues in term of the CPI index, $b_{i, t}$ is firm $i$ real amount of borrowing from the banking sector at the beginning of time $t$. The loan is used by the firm to pay the fixed production cost $f_{t}^{F}=f^{F}$ for the period $t$ to households ${ }^{22}$. Loans are paid back to the bank at the end of the same period at the net interest rate $r_{t}^{b}$. The variable $w_{t}$ is the real wage and $l_{i, t}$ is firm $i$ labor input. Using the retail sector demand and substituting for $w_{t} l_{i, t}=m c_{i, t} y_{i, t}$, the optimal problem can be rewritten as follows:

$$
\max _{\left\{P_{i, t}\right\}} E_{0} \sum_{t=0}^{\infty} \Lambda_{0, t}\left[\frac{P_{t}^{I}}{P_{t}}\left(\frac{P_{i, t}}{P_{t}^{I}}\right)^{1-\theta} y_{t}^{R}(k)-m c_{i t}\left(\frac{P_{i, t}}{P_{t}^{I}}\right)^{-\theta} y_{t}^{R}(k)-\left(1+r_{t}^{b}\right) f^{F}\right] .
$$

The FOC with respect to $P_{i, t}$ yields:

$$
\begin{aligned}
\frac{\partial \mathcal{L}}{\partial P_{i, t}^{I}} & =(1-\theta) \frac{P_{t}^{I}}{P_{t}^{I} P_{t}}\left(\frac{P_{i, t}}{P_{t}^{I}}\right)^{-\theta} y_{t}^{R}(k)+\theta m c_{i, t}\left(\frac{P_{i, t}}{P_{t}^{I}}\right)^{-\theta-1} \frac{y_{t}^{R}(k)}{P_{t}^{I}} \\
& =0
\end{aligned}
$$

Multiplying by $\frac{P_{t}^{I}}{y_{t}^{R}(k)}$ and rearranging we get:

$$
P_{i, t}=\frac{\theta}{\theta-1} m c_{i, t} P_{t}
$$

Equation (9) simply states that the optimal price of firm $i$ is a markup over its nominal marginal costs, $m c_{i, t}^{N o m}=m c_{i, t} P_{t}$. terms,

Then, defining $\rho_{i, t}=\frac{P_{i, t}}{P_{t}}$ we can rewrite the optimal price in relative

$$
\rho_{i, t}=\frac{\theta}{\theta-1} m c_{i, t}=\mu m c_{i, t}
$$

where $\mu=\frac{\theta}{\theta-1}$ is the gross markup.

\footnotetext{
${ }^{22}$ Since we assume that households are the owner of firms and their plants, the fixed cost can be viewed as a constant cost that a firm pay to household in each period for using its plant. Alternatively, the fixed cost can be viewed as a constant lump-sum tax payed by firms to the Government. Considering the latter assumption would not affect the main results of the paper.
} 
Distribution of Productivity Draws According to Melitz (2003) and Ghironi and Melitz (2005), firm productivity draws are Pareto distributed. The cumulative distribution function $(\mathrm{CDF})$ implied for productivity $z_{i, t}$ is $G\left(z_{i, t}\right)=1-\left(\frac{z_{\min }}{z_{i, t}}\right)^{\xi}$, while we denote by $g\left(z_{i, t}\right)=\xi \frac{z_{\min }^{\xi}}{z_{i, t}^{\xi+1}}$ the probability distribution function (PDF). The parameters $z_{\min }$ and $\xi>\theta-1$ are scaling parameters of the Pareto distribution, representing respectively the lower bound and the shape parameter, which indexes the dispersion of productivity draws. As $\xi$ increases dispersion decreases and firm productivity levels are increasingly concentrated towards their lower bound $z_{\min }$.

Endogenous Entry and Exit Prior to entry firms are identical and face a fixed sunk cost of entry $f^{E}>0$. Entrants are forward looking, so that the entry condition will be

$$
\tilde{v}_{t}=\widetilde{j}_{t}+\beta E_{t}\left(1-\eta_{t+1}\right) \tilde{v}_{t+1}=f^{E}
$$

where $\tilde{v}_{t}$ is the average firms value, given by the sum of current average profits, $\widetilde{j}_{t}$, and the next period discounted average value of firms, i.e. $\beta E_{t}\left(1-\eta_{t+1}\right) \tilde{v}_{t+1}$. Notice that $\tilde{v}_{t+1}$, is discounted not only by $\beta$ but also by the probability of firms default in the next period $\eta_{t+1}$. Notice that, when firms destruction is endogenous, the probability of firms default dynamically affects firms decision on entry, thus creating an important transmission channel between exit and entry decisions. Indeed, the higher the probability of firms' default, the lower is firms expected average value and thus the lower will be firms entry. Notice that with respect to Bilbiie at al (2012) the extra term $\widetilde{j}_{t}$ in the entry condition comes from the fact that we assume that there is no time to build for new entrants. Indeed, our timing assumptions are the following. Upon entrance new entrants borrow from the banks to pay the fixed production cost $f^{F}$. This cost is paid at the beginning of each production period by both new entrant and incumbent firms. ${ }^{23}$ Immediately after, they both draw their firm specific productivity level from a Pareto distribution. Then, the aggregate shock arrives and firms immediately start producing, unless they decide to exit. Exiting firms do not repay loans to banks. Using this timing assumption, the decision of new entrants to exit

\footnotetext{
${ }^{23}$ Notice that the entry cost and the production cost are two different cost. The first one is a sunk-cost payed only once and only by new entrants, before entering the market. While the second one is payed in every period by both firms types, i.e. incumbents and new entrants.
} 
the market is identical to the decision of incumbent firms. In particular, both new entrants and incumbent firms decide to produce as long as their specific productivity $z_{i, t}$ is above a cutoff level $\bar{z}_{t}$. The latter value is the level of productivity that makes the sum of current and discounted future profits (i.e. the firms value) equal to zero. Otherwise, firms will exit the market before producing. The cut off level of productivity, $\bar{z}_{t}$, is therefore determined by the following exit condition:

$$
v_{t}\left(\bar{z}_{t}\right)=j_{\bar{z}, t}\left(\bar{z}_{t}\right)+\beta E_{t}\left\{\left(1-\eta_{t+1}\right) v_{t+1}\left(\bar{z}_{t+1}\right)\right\}=0
$$

with

$$
j_{t}\left(\bar{z}_{t}\right)=y_{t}\left(\bar{z}_{t}\right)-w_{t} l_{\bar{z}, t}-\left(1+r_{t}^{b}\right) f^{F},
$$

where $j_{t}\left(\bar{z}_{t}\right)$ are current profits of the firm with a productivity $z_{i, t}=\bar{z}_{t}$. In other words, before they start producing both new entrants and incumbents know exactly their time $t$ profits. Consequently, if the sum of these profits and of all their expected future profits is non-positive they will exit the market before producing. The exit probability $\eta_{t+1}=1-\left(\frac{z_{\min }}{\bar{z}_{t+1}}\right)^{\xi}$ is thus endogenously determined. As in Ghironi and Melitz (2005), the lower bound productivity $z_{\min }$ is low enough relative to the production costs so that $\bar{z}_{t}$ is above $z_{\min }$. In each period, this ensures the existence of an endogenously determined number of exiting firms: the number of firms with productivity levels between $z_{\min }$ and the cutoff level $\bar{z}_{t}$ are separated and exit the market without producing.

Notice that, under these assumptions the number of firms in the economy at period $t$ will be:

$$
N_{t}=\left(1-\eta_{t}\right)\left(N_{t-1}+N_{t}^{E}\right)
$$

\subsection{Average and Aggregate Variables}

From now on for any generic variable $x$ we use $x_{i, t}=x_{i, t}\left(z_{i, t}\right)$ to indicate a variable belonging to the firm with productivity equal to $z_{i, t}$. Analogously $x\left(\tilde{z}_{t}\right)$ indicates the value of the same variable belonging to the firm whose productivity is equal to the average productivity $\tilde{z}_{t}$. We define the average value of the variable $x$ as $\tilde{x}$. We show that not always $\tilde{x}=x\left(\tilde{z}_{t}\right)$. Finally, we define aggregate variables using capital letters. 


\subsubsection{Firms Average Productivity}

Following Ghironi and Melitz (2005), the average productivity of the intermediate good sector is:

$$
\tilde{z}_{t} \equiv\left[\frac{1}{1-G\left(\bar{z}_{t}\right)} \int_{\bar{z}_{t}}^{\infty} z_{i, t}^{1-\theta} d G\left(z_{i, t}\right)\right]^{\frac{1}{\theta-1}}
$$

where $1-G\left(\bar{z}_{t}\right)=\left(\frac{z_{\min }}{\bar{z}_{t}}\right)^{\xi}$ is the share of firms with a level of productivity $z_{i, t}$ above the cut off level $\bar{z}_{t}$. In other words, it is the firms' probability to remain in the market and produce at time $t$.

\subsubsection{Aggregate Price Index and the Average Relative Price: the Intermediate Sector}

The aggregate price level of the intermediate sector $k$ is defined as

$$
\begin{aligned}
P_{t}^{I}(k) & =\left[\frac{1}{1-G\left(\bar{z}_{t}\right)} \int_{\bar{z}_{t}}^{\infty} N_{t}\left(P_{i, t}\right)^{1-\theta} g\left(z_{i}\right) d z_{i}\right]^{\frac{1}{1-\theta}} \\
& =N_{t}^{\frac{1}{1-\theta}}\left[\frac{1}{1-G\left(\bar{z}_{t}\right)} \int_{\bar{z}_{t}}^{\infty}\left(P_{i, t}\right)^{1-\theta} g\left(z_{i}\right) d z_{i}\right]^{\frac{1}{1-\theta}}
\end{aligned}
$$

since each intermediate sector $k$ faces the demand of the retail sector $k$, solving the Dixit Stiglitz problem of the retail sector we find that the demand of good $i$ is $y_{i, t}\left(z_{i, t}\right)=\left(\frac{P_{i, t}}{P_{t}^{I}(k)}\right)^{-\theta} Y_{t}^{R}(k)$, where $Y_{t}^{R}(k)$ is the aggregate demand of the retailer $k$. Solving for $P_{i, t}$

$$
P_{i, t}=\left(\frac{y_{i, t}\left(z_{i, t}\right)}{Y_{t}^{R}(k)}\right)^{-\frac{1}{\theta}} P_{t}^{I}(k)
$$

and thus

$$
P_{t}\left(\tilde{z}_{t}\right)=\left(\frac{y_{t}\left(\tilde{z}_{t}\right)}{Y_{t}^{R}(k)}\right)^{-\frac{1}{\theta}} P_{t}^{I}(k)
$$

is the price of the firm with the average productivity $\tilde{z}_{t}$. Using (17) we can rewrite (16) as

$$
P_{t}^{I}(k)=N_{t}^{\frac{1}{1-\theta}}\left[\frac{1}{1-G\left(\bar{z}_{t}\right)} \int_{\bar{z}_{t}}^{\infty}\left(\left(\frac{y_{i, t}\left(z_{i, t}\right)}{Y_{t}}\right)^{-\frac{1}{\theta}} P_{t}^{I}(k)\right)^{1-\theta} g\left(z_{i}\right) d z_{i}\right]^{\frac{1}{1-\theta}} .
$$


As shown in Melitz (2003) the relative output shares between two firms imply that $\frac{y_{i, t}\left(z_{i}\right)}{y_{k, t}\left(z_{k}\right)}=\left(\frac{z_{i, t}}{z_{k, t}}\right)^{\theta}$, and then $\frac{y_{i, t}\left(z_{i, t}\right)}{y_{t}\left(\tilde{z}_{t}\right)}=\left(\frac{z_{i, t}}{\tilde{z}_{t}}\right)^{\theta}$. Using this result we can rewrite ${ }^{24}$

$$
P_{t}^{I}(k)=N_{t}^{\frac{1}{1-\theta}} P_{t}^{I}(k)\left(\frac{y_{t}\left(\tilde{z}_{t}\right)}{Y_{t}}\right)^{-\frac{1}{\theta}},
$$

using equation (18) it implies that

$$
P_{t}^{I}(k)=N_{t}^{\frac{1}{1-\theta}} P_{t}\left(\tilde{z}_{t}\right)
$$

Due to symmetry across retail sector firms $P_{t}^{I}(k)=P_{t}^{I}$. Then, the aggregate price index of the intermediate sector is

$$
P_{t}^{I}=N_{t}^{\frac{1}{1-\theta}} P_{t}\left(\tilde{z}_{t}\right)
$$

Finally, since

$$
P_{t}\left(\tilde{z}_{t}\right)=\left[\frac{1}{1-G\left(\bar{z}_{t}\right)} \int_{\bar{z}_{t}}^{\infty}\left(P_{i, t}\right)^{1-\theta} g\left(z_{i}\right) d z_{i}\right]^{\frac{1}{1-\theta}}
$$

the average relative price is given by

$$
\frac{P_{t}\left(\tilde{z}_{t}\right)}{P_{t}^{I}} \frac{P_{t}}{P_{t}}=N_{t}^{\frac{1}{\theta-1}}
$$

and then

$$
\rho\left(\tilde{z}_{t}\right)=N_{t}^{\frac{1}{\theta-1}} \rho_{t}^{I}
$$

where we define $\rho\left(\tilde{z}_{t}\right)=\frac{P_{t}\left(\tilde{z}_{t}\right)}{P_{t}}$ and $\rho_{t}^{I}=\frac{P_{t}^{I}}{P_{t}}$.

Similarly, firms average profits are

$$
\widetilde{j}_{t}=j\left(\widetilde{z}_{t}\right)=\rho^{I} N_{t}^{-1} Y_{t}-w_{t} N_{t}^{-1} L_{t}-\left(1+r_{t}^{b}\right) f^{F},
$$

thus, they coincide with the profits of the firm that obtains the average productivity $\widetilde{z}_{t} \cdot{ }^{25}$

\footnotetext{
${ }^{24}$ See the Technical Appendix for details.

${ }^{25}$ The derivation of average real profits and the proof for $\widetilde{j}_{t}=j\left(\widetilde{z}_{t}\right)$ is in the Technical Appendix.
} 


\subsubsection{Firms: Retailers}

For the sake of simplicity we assume one-to-one relation between the number of retail sectors and the number of intermediate good-producing sectors. Each retailer $k \in(0,1)$ in the retail sector bundles the goods produced by the intermediate sector $k$ under monopolistic competition, facing Rotemberg (1982) price adjustment costs. The new good of the retailer $k$ is thus,

$$
Y_{t}^{\varrho}(k)=\left[\int_{N_{t}} y_{i, t}^{\frac{\theta-1}{\theta}} d i\right]^{\frac{\theta}{\theta-1}} .
$$

This good is sold to the household at the price $P_{k, t}^{R}$. Since all firms in the retail sector are identical, they all set the same price maximizing their real profits, $j_{k, t}^{R}$ given by:

$$
\begin{aligned}
j_{k, t}^{R}= & \frac{P_{k, t}^{R}}{P_{t}} Y_{t}^{R}(k)-\frac{\int_{N_{t}} P_{i, t} y_{i, t}}{P_{t}}-p a c_{k, t}, \\
& \text { s.t. }: Y_{t}^{R}(k)=\left(\frac{P_{k, t}^{R}}{P_{t}}\right)^{-\theta} Y_{t}^{d}
\end{aligned}
$$

where $Y_{t}^{R}(k)=\left(\frac{P_{k, t}^{R}}{P_{t}}\right)^{-\theta} Y_{t}^{d}$ is the household demand for the differentiated final good $k$, with $P_{t}$ being the CPI index, while $Y_{t}^{d}$ is the aggregate demand for output. The term $\operatorname{pac}_{k t}=\frac{\tau}{2}\left(\frac{P_{k, t}}{P_{k, t-1}}-1\right)^{2} \frac{P_{k, t}}{P_{t}} Y_{t}^{R}(k)$ represents the Rotemberg (1982), with $\tau>0$. After solving the Dixit Stiglitz problem, according to which $P_{t}^{I}(k) Y_{t}(k)=\int_{N_{t}} P(i) y_{t}(i) d i$, profits of the retail firm $k$ can be rewritten as:

$$
J_{k, t}^{R}=\left(\frac{P_{k, t}^{R}}{P_{t}}-\frac{P_{t}^{I}}{P_{t}}\right) Y_{t}^{R}(k)-\frac{\tau}{2}\left(\frac{P_{k, t}^{R}}{P_{k, t-1}^{R}}-1\right)^{2}\left(\frac{P_{k, t}^{R}}{P_{t}}\right)^{1-\theta} Y_{t}^{d},
$$

and we can write the profit maximization function as,

$$
\begin{aligned}
& \max _{\left\{P_{k, t}\right\}} E_{0} \sum_{t=0}^{\infty} \Lambda_{0, t} J_{k, t}^{R} \\
& \text { s.t. } \\
Y_{t}^{R}(k)= & \left(\frac{P_{k, t}^{R}}{P_{t}}\right)^{-\theta} Y_{t}^{d}
\end{aligned}
$$


Substituting the constraint and solving for $P_{k, t}^{R}$ and imposing the symmetric equilibrium, that is $P_{k, t}^{R}=P_{t}$ and $Y_{t}^{R}(k)=Y_{t}$ yields to:

$$
\begin{aligned}
& (1-\theta)+\theta \rho_{t}^{I}-\tau\left(\pi_{t}-1\right) \pi_{t}-(1-\theta) \frac{\tau}{2}\left(\pi_{t}-1\right)^{2}+ \\
& +E_{t}\left\{\Lambda_{t, t+1} \tau\left(\pi_{t+1}-1\right) \pi_{t+1} \frac{Y_{t+1}}{Y_{t}}\right\} \\
= & 0
\end{aligned}
$$

where $\pi_{t}=\frac{P_{t}}{P_{t-1}}$ is the gross inflation rate and where the stochastic discount factor, $\Lambda_{t, t+1}$, is defined as:

$$
E_{t} \Lambda_{t, t+1}=\beta E_{t}\left\{\left(\frac{C_{t+1}}{C_{t}}\right)^{-1}\left(1-\eta_{t+1}\right)\right\} .
$$

Notice that, since the exit probability changes along the business cycle, it now affects the dynamics of the stochastic discount factor.

\subsection{Aggregate Output and Price}

Aggregate output is given by the following CES technology:

$$
Y_{t}=\left[\int_{0}^{1}\left(Y_{k, t}\right)^{\frac{\theta-1}{\theta}} d k\right]^{\frac{\theta}{\theta-1}}
$$

the aggregate price index is:

$$
P_{t}=\left[\int_{0}^{1} P_{k, t}^{1-\theta} d k\right]^{\frac{1}{1-\theta}}
$$

The Technical Appendix shows that the aggregate price and output can be rewritten as,

$$
\begin{gathered}
P_{t}=N_{t}^{\frac{1}{1-\theta}} P_{t}\left(\tilde{z}_{t}\right)\left(\rho_{t}^{I}\right)^{-1}, \\
Y_{t}=N_{t}^{\frac{\theta}{\theta-1}} y_{t}\left(\tilde{z}_{t}\right)=\rho_{t}\left(\tilde{z}_{t}\right) A_{t} \tilde{z}_{t} L_{t} .
\end{gathered}
$$




\subsection{Households}

Households maximize their expected utility, which depends on consumption and labor hours as follows,

$$
\max E_{0} \sum_{t=0}^{\infty} \beta^{t}\left(\ln C_{t}-\frac{L_{t}^{1+\phi}}{1+\phi}\right),
$$

where $\beta \in(0,1)$ is the discount factor and the variable $L_{t}$ represents hours worked, while $C_{t}$ is the usual consumption index:

$$
C_{t}=\left(\int_{0}^{1} C_{k, t} \frac{\theta-1}{\theta} d j\right)^{\frac{\theta}{\theta-1}}
$$

where $C_{k, t}=\left(\int_{i \in N} C_{i, t} \frac{\theta-1}{\theta} d i\right)^{\frac{\theta}{\theta-1}}$ is the good bundled by the retail sector and $C_{i, t}$ the production of the intermediate good-producing firm $i$. The parameter $\theta$ (being $\theta>1$ ) is the elasticity of substitution between the goods produced in each sector. Households consume and work. They also decide how much to invest in new firms and in the shares of incumbent firms and how much to lend to the banking sector.

Households enter the period $t$ earning an income from the deposits owned in the previous period $\frac{r_{t-1}^{d}}{\pi_{t}} D_{t-1}$, they then invest in a mutual fund of firms given by the sum of the already existing firms $N_{t-1}$ and the new entrants at time $t, N_{t}^{E}$, where $\gamma_{t}$ is the share of the mutual fund of firms held by the household, and $\widetilde{v}_{t}$ is the price paid, i.e. the firm value at the beginning of the period $t$. As previously discussed, both new entrants and incumbents firms borrow from the banking sector to pay the fixed production cost, they draw their firms specific productivity and then, after observing the aggregate shock, they decide whether to produce or exit the market. Those firms that are not separated produce and distribute their dividends $j_{t}(\tilde{z})$ to the household at the end of time $t$. At the end of the same period, the average value of the same share $\gamma_{t}$ of mutual fund of firms will be $\widetilde{v}_{t+1}$. In addition to the labor income $w_{t} L_{t}$, and to the fixed costs received by the intermediate producers $F^{F}=N_{t} f^{F}$, households use dividends $j_{t+1}(\tilde{z})$, the new value of the mutual fund $\widetilde{v}_{t+1}$ and profits from retailers, $j_{t}^{R}$, to consume $C_{t}$ or to save 
in the form of new deposits $D_{t}$. Thus, the household budget constraint is:

$w_{t} L_{t}+F^{F}+\frac{r_{t-1}^{d}}{\pi_{t}} D_{t-1}+\underbrace{N_{t} \gamma_{t}\left(\widetilde{v}_{t+1}+j_{t+1}(\tilde{z})\right)}_{\text {End of period } t}+j_{t}^{R}=C_{t}+\left(D_{t}-\frac{D_{t-1}}{\pi_{t}}\right)+\underbrace{\left(N_{t-1}+N_{t}^{E}\right) \widetilde{v}_{t} \gamma_{t}}_{\text {Beginning of period } t}$,

with

$$
N_{t}=\left(1-\eta_{t}\right)\left(N_{t-1}+N_{t}^{E}\right) .
$$

Taking the first order conditions with respect to $\gamma_{t}, D_{t}, C_{t}, L_{t}$, combining households FOCs and imposing that in equilibrium $\gamma_{t}=\gamma_{t+1}=1$, yields:

$$
\begin{gathered}
w_{t}=C_{t} L_{t}^{\phi}, \\
E_{t} \beta\left\{\left(\frac{C_{t+1}}{C_{t}}\right)^{-1}\right\}=\frac{\pi_{t+1}}{\left(1+r_{t}^{d}\right)}, \\
\widetilde{v}_{t}=E_{t} \beta\left\{\left(\frac{C_{t+1}}{C_{t}}\right)^{-1}\left(1-\eta_{t+1}\right)\left[\widetilde{v}_{t+1}+\widetilde{j}_{t+1}\right]\right\},
\end{gathered}
$$

which are respectively the households' labor supply, the Euler equation for consumption and the Euler equation for share holding.

\subsection{The Banking Sector}

\subsubsection{Loans and Deposits Branches}

The structure of the banking sector is borrowed from Gerali et al. (2010). We assume that the bank is composed by two branches: the loan branch and the deposit branch. Both are monopolistic competitive, so that deposits from households and loans to entrepreneurs are a composite CES basket of a continuum of slightly differentiated products $j \in(0,1)$, each supplied by a single bank with elasticities of substitution equal to $\varepsilon^{b}$ and $\varepsilon^{d}$ respectively. As in the standard Dixit-Stiglitz (1977) framework, loans and deposits demands are:

$$
b_{j, t}=\left(\frac{r_{j, t}^{b}}{r_{t}^{b}}\right)^{-\varepsilon^{b}} b_{t} \quad \text { and } \quad d_{j, t}=\left(\frac{r_{j, t}^{d}}{r_{t}^{d}}\right)^{-\varepsilon^{d}} d_{t}
$$

where $b_{j, t}$ is the aggregate demand for loans at bank $j$, that is $b_{j, t}=\int_{0}^{1} b_{k, j, t} d k=$ $\int_{0}^{1}\left[\int_{i \in N} b_{i, j, t} d i\right]$, where $b_{k, j, t}$ is the total amount of loans demanded to bank 
$j$ by sector $k$ and $b_{t}$ is the overall volume of loans to firms. Similarly, $d_{j, t}$ is the households aggregate demand for deposits to bank $j$, while $d_{t}$ is the households overall demand for deposits.

The amount of loans issued by the loan branch can be financed through the amount of deposits, $D_{t}$, collected from households from the deposit branch or through bank capital (net-worth), denoted by $K_{t}^{b}$, which is accumulated out of retained earnings. Thus, the bank sector obey a balance sheet constraint,

$$
B_{t}=D_{t}+K_{t}^{b},
$$

with the low of motion of the aggregate banking capital given by:

$$
\pi_{t} K_{t}^{b}=\left(1-\delta^{b}\right) K_{t-1}^{b}+j_{t}^{b},
$$

where $\delta^{b}$ represents resources used in managing bank capital, while $j_{t}^{b}$ are overall profits made by the retail branches of the bank.

Loans Rates and Deposits Rates Banks play a key role in determining the conditions of credit supply. Assuming monopolistic competition, banks enjoy market power in setting the interest rates on deposits and loans. This leads to explicit monopolistic markups and markdowns on these rates.

Each bank $j$ belonging to the loan branch can borrow from the deposit bank $j$ at a rate $R_{j t}^{b}$. We assume that banks have access to unlimited finance at the policy rate $r_{t}$ from a lending facility at the central bank: hence, by the non-arbitrage condition $R_{j, t}^{b}=r_{t}$. The loan branch differentiates the loans at no cost and resell them to the firms applying a markup over the policy rate. ${ }^{26}$ As in Curdia and Woodford (2009) we assume that banks are unable to distinguish the borrowers who will default from those who will repay, and so must offer loans to both on the same terms. The problem of the loan bank $j$ is therefore,

$$
\begin{aligned}
& \max _{\left\{r_{j, t}^{b}\right\}} E_{0} \sum_{t=0}^{\infty} \Lambda_{0, t}\left[r_{j, t}^{b} b_{j, t}\left(1-\eta_{t}\right)-r_{t} B_{j, t}-b_{j, t} \eta_{t}\right], \\
& \text { s.t. } \quad b_{j, t}=\left(\frac{r_{j, t}^{b}}{r_{t}^{b}}\right)^{-\varepsilon^{b}} b_{t},
\end{aligned}
$$

\footnotetext{
${ }^{26}$ All banks essentially serve all firms, providing slightly differentiated deposit and loan contracts.
} 
where $b_{j, t}=\left(\frac{r_{j, t}^{b}}{r_{t}^{b}}\right)^{-\varepsilon^{b}} b_{t}$ is the demand for loans of bank $j, r_{j, t}^{b} b_{j, t}\left(1-\eta_{t}\right)$ are bank $j$ net revenues, while $r_{t} B_{j, t}$ is the net cost due to the interest rate paid on the deposit rates. The additional term $b_{j, t} \eta_{t}$ is the amount of the notional value of the loans that it is not repaid by firms. This is a death weight loss for the bank and represents an extra-cost. From the FOC, after imposing symmetry across banks, i.e. $r_{j, t}^{b}=r_{t}^{b}$, and thus $b_{j, t}=b_{t}$ and $B_{j, t}=B_{t}=N_{t} f^{F}$, we get the equation for the optimal interest rate:

$$
r_{t}^{b}=\left(\frac{\varepsilon^{b}}{\left(\varepsilon^{b}-1\right)\left(1-\eta_{t}\right)}\right)\left(r_{t}+\eta_{t}\right),
$$

where $\mu_{t}^{L b}=\frac{\varepsilon^{b}}{\left(\varepsilon^{b}-1\right)\left(1-\eta_{t}\right)}$ is the bank markup and $r_{t}+\eta_{t}$ is its marginal cost. ${ }^{27}$ The bank marginal cost is the sum of two components: i) $r_{t}$, i.e. the net interest rate that the bank has to pay to the deposit branch for each loan. This is the only effective cost per loan in the case the bank is able to have back the notional value of the loan from defaulting firms. ii) $\eta_{t}$ represents instead the additional cost per loan faced by the bank due to firms defaulting and not repaying the loan.

Notice that $\frac{d\left(\mu_{t}^{L b}\right)}{d \eta_{t}}=\frac{1}{\varepsilon^{b}-1} \frac{\varepsilon^{b}+1}{\left(\eta_{t}-1\right)^{2}}>0$, implying a positive relationship between firms' exit and the value of the bank markup. Indeed, as the expected probability of exit increases, retail banks increase their markup and set higher interest rate. The intuition is straightforward. An increase in the firms' exit probability imply that the probability that a firm do not repay the loan increases. As a consequence the bank that has issued that loan faces lower expected profits. To restore its profits the bank is forced to increase the interest rate on loan.

The deposit branch collects deposits from households and gives them to the loans unit, which pays $r_{t}$. The problem for the deposit branch is then

\footnotetext{
${ }^{27}$ Indeed, in the symmetric equilibrium total costs are given by $C T_{t}^{b}=r_{t} b_{t}+b_{t} \eta_{t}$. Thus bank's marginal costs are $M C_{t}^{b}=\frac{d C T_{t}^{b}}{d b_{t}}=r_{t}+\eta_{t}$.
} 


$$
\begin{aligned}
& \max _{\left\{r_{j, t}^{d}\right\}} E_{0} \sum_{t=0}^{\infty} \Lambda_{0, t}\left[r_{t} D_{j, t}-r_{j, t}^{d} d_{j, t}-\frac{\kappa_{d}}{2}\left(\frac{r_{j, t}^{d}}{r_{j, t-1}^{d}}-1\right)^{2} r_{t}^{d} d_{t}\right], \\
& \text { s.t. } \\
d_{j, t}= & \left(\frac{r_{j, t}^{d}}{r_{t}^{d}}\right)^{-\varepsilon^{d}} d_{t} \text { and } D_{j, t}=d_{j, t}
\end{aligned}
$$

where $d_{j, t}=\left(\frac{r_{j, t}^{d}}{r_{t}^{d}}\right)^{-\varepsilon^{d}} d_{t}$ is the demand for deposits of bank $j$. From the FOC, after imposing symmetry across banks, i.e. $r_{j, t}^{d}=r_{t}^{d}$, and thus $d_{j, t}=d_{t}$ and $D_{j, t}=D_{t}$, we get the optimal interest rate for deposits,

$$
r_{t}^{d}=\frac{\varepsilon^{d}}{\varepsilon^{d}-1} r_{t}
$$

$\frac{d\left(\frac{\varepsilon^{d}}{\varepsilon^{d}-1}\right)}{d \varepsilon^{d}}=-\frac{1}{\left(\varepsilon^{d}-1\right)^{2}}<0$, i.e. the interest rate on deposits is markdown over the policy rate $r_{t}$.

Aggregate bank profits are the sum of the profits of the branches of the bank. Thus, they are also affected by the firms' exit probability and given by:

$$
j_{t}^{b}=r_{t}^{b} B_{t}\left(1-\eta_{t}\right)-r_{t}^{d} D_{t}-B_{t} \eta_{t}
$$

where $B_{t} \eta_{t}$ is the total amount of the loans not repaid to the banks.

\subsection{Monetary Policy}

To close the model we specify an equation for the Central Bank behavior. We simply assume that the monetary authority set the nominal interest rate $r_{t}$ following a Taylor-type rule given by

$$
\ln \left(\frac{1+r_{t}}{1+r}\right)=\phi_{R} \ln \left(\frac{1+r_{t-1}}{1+r}\right)+\left(1-\phi_{R}\right) \phi_{\pi} \ln \left(\frac{\pi_{t}}{\pi}\right),
$$

where $\ln \left(\frac{\pi_{t}}{\pi}\right)$ is the deviations of inflation from its steady state values, $\phi_{\pi}$ being the elasticities of the nominal interest rate with respect to these deviations. Finally, $\phi_{r}$ is the interest rate smoothing parameter. 


\section{Calibration and Model Dynamics}

Calibration is set on a quarterly basis. The discount factor, $\beta$, is set at 0.99. The parameter related to the Frisch elasticity of the labor supply $\phi$ is set at 4. As in BGM (2012), we set the steady state value of the exit probability $\eta$ to be 0.025 , this needs that $\xi$ is set equal to 7.85 . A value of $\eta=0.025$ matches the U.S. empirical evidence of $10 \%$ of firms destruction per year. The elasticity of substitution among intermediate goods, $\theta$, is set equal to 3.8, a value which is in line with Ghironi and Melitz (2005) and BGM (2012). It also ensures that the condition for the shape parameter $\xi>\theta-1$ is satisfied in the model with endogenous exit. The lower bound of productivity distribution, $z_{\text {min }}$, is equal to 1. Further, as in BGM (2012), Etro and Colciago (2010) and Colciago and Rossi (2012), we set the entry cost $f^{E}=1$. The fixed costs $f^{F}$ is set such that in all the economies considered they correspond to $5 \%$ of total output produced. We translate the Rotemberg cost of adjusting prices, $\tau$, into an equivalent Calvo probability that firms do not adjusted prices equal to 0.67, a value close to the ones obtained in the empirical literature (see for example Smets and Wouters (2007) and Christiano et al 2005, among others).

We calibrate the banking parameters as in Gerali et al. (2010). For the deposit rate, we calibrate $\varepsilon^{d}=-1.46$. Similarly, for loan rates we calibrate $\varepsilon^{b}=3.12$. The steady-state ratio of bank capital to total loans, i.e. the capital-to-asset ratio, is set at 0.09. We consider a Taylor rule, with $\phi_{R}=0.75, \phi_{\pi}=2$.This rule guarantees the uniqueness of the equilibrium. Further, these parameters are in the range of the values estimated for the US economy. ${ }^{28}$

Finally, the calibration of the parameters of the productivity shock is based on our VAR evidence. As discussed in the empirical section, the labor productivity shock raises the measure of labor productivity by 0.25 percent points relative to the sample mean of 1.945 . Thus, the shock is equivalent to a $0.1285 \%$ percent increase in the level of productivity relative to its mean (i.e. $0.25 / 1.945=0.001285$ ). Since we calibrate the mean of the productivity shock to 1 , in our model we set the standard deviation of the productivity shock to $\sigma_{A}=0.001285$ in line with the empirical evidence. Our evidence also suggests that the effects of the labor productivity shock

\footnotetext{
${ }^{28}$ See for example Smets and Wouters (2007). The qualitative results and the comparison with the exogenous exit model and with the model with efficient banks are not qualitatively altered by the choice of the Taylor rule.
} 
gradually decline over time with a persistence equal to 0.93. Thus, in our model we set the persistence of the productivity shock, $\rho_{A}$, to 0.93 .

\subsection{Productivity Shocks}

We now show the IRFs to a positive shock productivity shock. To capture the importance of the endogenous exit mechanism, we compare the IRFs of our baseline model (labeled as Endogenous Exit) with those of a model where firms exit probability is exogenous and constant (labeled as Exogenous Exit). In both models the banking sector is characterized by monopolistic competition and defaulting firms do not repay the loan.

Then, to better understand the role played by banks, we compare our baseline model with a model without banks where firms self finance their activity.

Finally, using simulated data from our model, we show that our empirical identification strategy can recover the true macroeconomic effects of a positive productivity shock.

\subsubsection{Endogenous versus Exogenous Exit}

Figure 3 shows the IRFs to a positive shock to the level of productivity, $A_{t}$, in the the baseline model and in the model with exogenous exit. Notice that, a positive productivity shock lowers real marginal costs and creates expectations of future profits which lead to the entry of new firms in both models. The entry margin results in a strong and persistent increase in output. This is the standard propagation mechanism implied by the BGM (2012) model. With the introduction of the endogenous exit margin, the number of firms exiting the market becomes countercyclical at impact. However after three periods firms destruction overshoots persistently its long run level. After seven years the variable is still above its steady state value. The response of output is hump-shaped in both models, but it picks at an higher value in the model with endogenous exit. Thus the propagation of the shock is much stronger in the model with endogenous firms destruction. The reason is threefold. First, in this model, the increase in productivity leads to higher profits and thus to a lower cut-off level of productivity, $\bar{z}_{t}$. Firms' exit probability reduces and firms' destruction decreases, further amplifying the response of output. Second, the decision of firms to enter the market depends on firms exit probability also. Thus, the response of new entrants is 
stronger in the endogenous exit model. Third, a decrease in the exit probability implies an higher probability for firms to repay the loan, which in turn induces banks to reduce their markups. This means that banks markup are countercyclical in the model with endogenous exit. Firms' cost for borrowing reduces, further reducing firms profits and thus giving an extra boost to output. To sum up, the model with endogenous exit matches the three stylized facts found in our empirical analysis, that is: i) the procyclicality of firms creation; ii) the countercyclicality and the overshooting of firms' destruction. Consistently with our empirical analysis, after seven years firms destruction is still above its long run level. Finally, iii) bank markup is countercyclical.

The counterfactual. on firms destruction implied by the model with exogenous exit, depends exclusively on having assumed an exogenous and constant exit probability. The model with exogenous exit also implies an exogenous and constant banks' markup. ${ }^{29}$
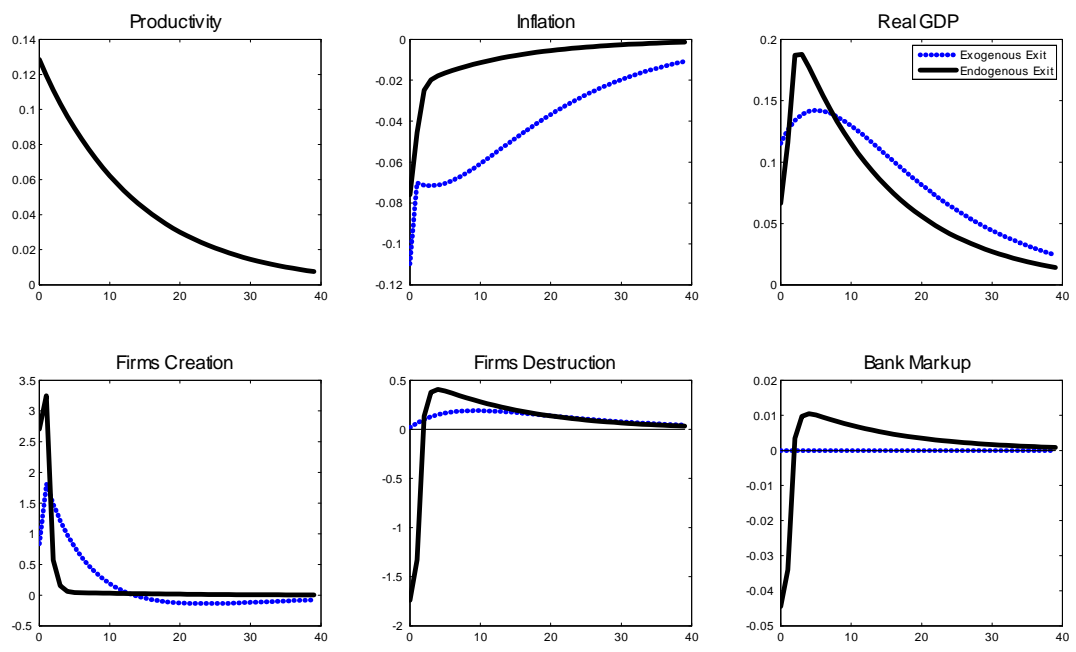

Figure 3: IRFs to a positive productivity shock. Endogenous versus exogenous exit model

\footnotetext{
${ }^{29}$ We are aware that banks' markups may be affected by other important economic variables. However, in our paper we are interested to capture the relationship between firms' default and the banks' markup. For this reason, and also to leave the model as simple as possible, we do not consider the effects of any other variable that may affect the dynamics of the bank markup.
} 


\subsubsection{The Role of Financial Intermediaries}

This Section compares the baseline model with a model without banks, that is with a model where financial intermediaries are absent and firms self finance their payments. ${ }^{30}$ For comparative reasons, the calibration of the model coincides with the baseline one.
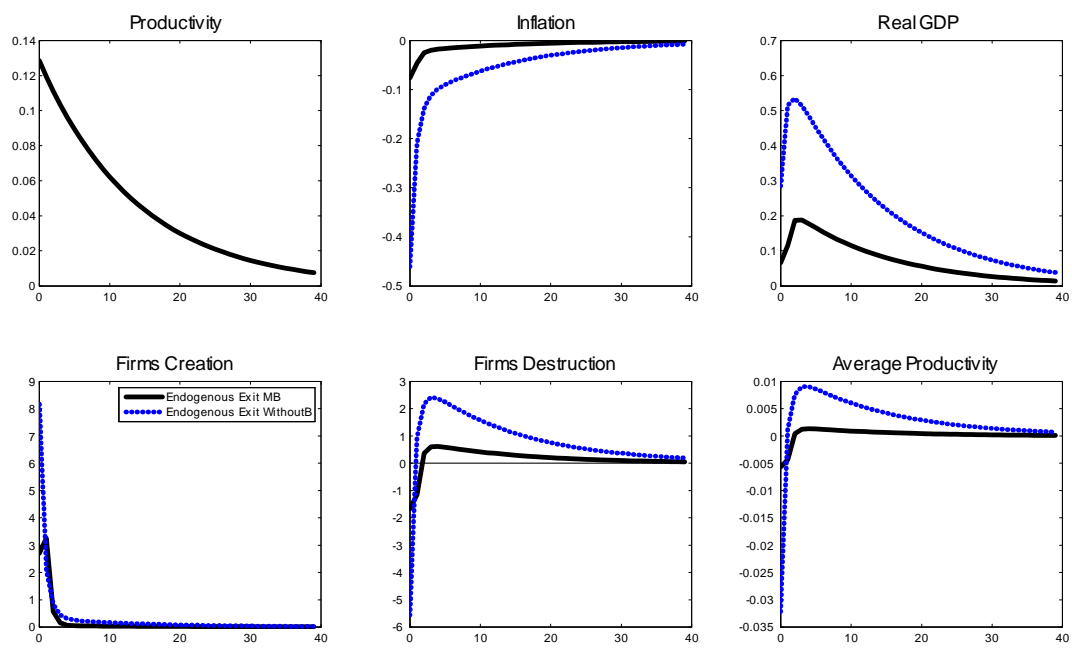

Figure 4: IRFs to a positive productivity shock. Endogenous Exit model with Monopolistic Banks versus Endogenous Exit model without Banks.

Figure 4 shows that results remain qualitatively unaltered. However, the model without banks strongly amplifies the effect of the shock. Firms creation jumps on impact and increases more than twice with respect to the baseline model. Similarly firms destruction falls by a stronger amount and its overshooting is much more amplified. As a result, the hump-shaped response of output is higher and more persistent. The intuition is simple. First of all, when firms can self finance they face lower costs and thus higher profits. Thus, as the productivity shock hits the economy the amount of firms above the cut-off increases by an higher amount than in the baseline model, implying ceteris paribus an higher fall in firms destruction at impact. Since the decision to enter depends on exit probability, firms creation is also higher. As a result, output increases more at impact than in the baseline model. To better understand the response of output we plot the

\footnotetext{
${ }^{30}$ Both wages and fixed costs are self financed and payed by firms in terms of output.
} 
response of firms average productivity. Notice that, in both model firms average productivity decreases at impact, However, the huge decrease in firms destruction and the higher increase in entry contributes enlarge the number of firms with low productivity and to reduce firms average productivity. As soon as the aggregate productivity shock starts reverting to its lower steady state level, the cut-off level of productivity reduces, so that those firms with a low productivity exit the market overshooting their long-run value. As firms exit increases, firms average productivity increases also overshooting its long-run value. The response of output is thus higher and more persistent in the model without banks than in the baseline model.

Remarkably, notice that the IRFs of our baseline model are closer to the empirical ones, implying that the banking sector helps to reproduce the evidence found in the BVAR.

\subsubsection{BVAR versus DSGE}

We now compare the IRFs implied by our calibrated model, i.e. the ones shown in Figure 1 (solid and black lines), with the IRFs generated by a BVAR estimated using data generated by the same model. We employ the same identification used for the structural BVAR in Section 3. Simulated data are obtained as follows. We solve the model under the calibration used to obtained the IRFs reported in Figure 1, we then generate a dataset of 25000 observations, including productivity, output, inflation, firms destruction, firms creation and the bank markup. ${ }^{31}$ We drop the first 10000 observation and we estimate a BVAR of 15000 observations. Figure 5 shows the performance of the Cholesky-BVAR in replicating the DSGE model consistent IRFs. Notice that the responses obtained with the BVAR are qualitatively identical to the ones obtained in the baseline model. This confirms that productivity shock is correctly identified in our empirical section. However, notice the BVAR underestimates the impact responses of firms' creation and destruction.

\footnotetext{
${ }^{31}$ We solve the model using alternatively a first order approximation and a second order approximation. In the first case, to avoid singularity of the data generated matrix, we hit the economy with six shocks (a productivity shock, a bank capital shock and four measurement error shocks). In the second case we consider just the first two. We show the results obtained using a second order approximation. The IRFs obtained under first order approximation are not reported, since they overlap with the other ones. They are available upon request.
} 

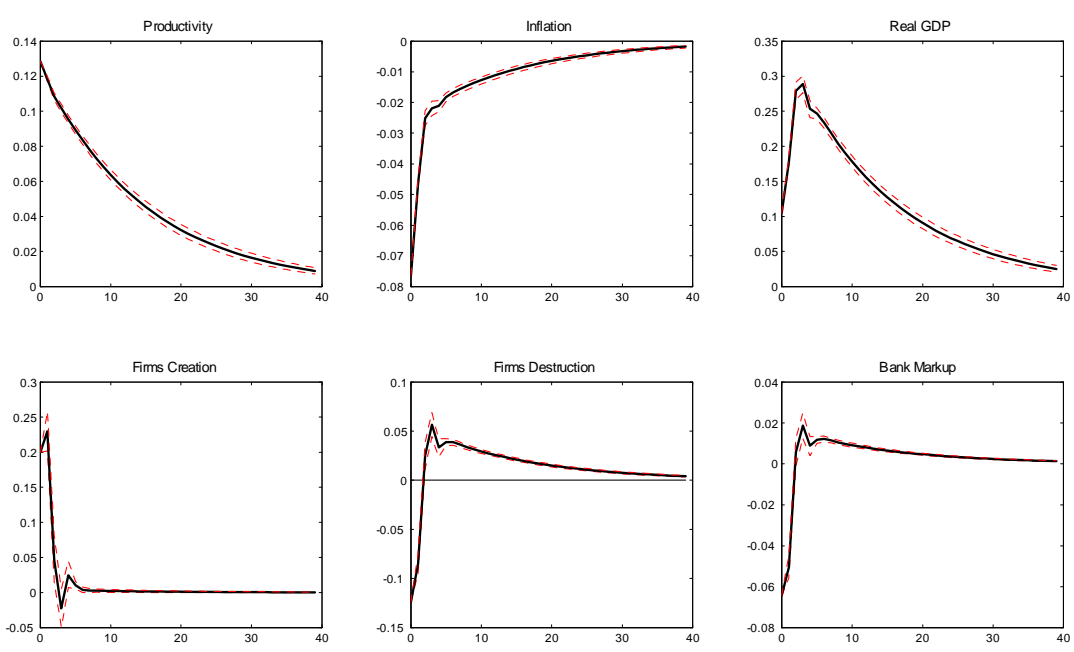

Figure 5. IRFs to a productivity shock: BVAR on Simulated Data

\section{Conclusion}

We develop a NK-DSGE model with endogenous firms dynamics together with a monopolistic banking sector, where defaulting firms do not repay loans to banks. We analyze the relationship between firms dynamics and banking in response to a shock to the level of the aggregate productivity. We show that our model replicates some important stylized facts in response to a productivity shock. First, the procyclicality of firms creation. Second, the countercyclicality and the long-lasting overshooting of firms destruction. Third, the countercyclicality of the bank markup. Also, we show that the model with banks outperforms the model without banks in terms of ability to replicate the estimated IRFs. This confirms that embodying financial intermediaries in the DSGE model helps to replicate the empirical facts. Finally, contrary to the conventional wisdom, the effect of the shock are amplified in a model where financial intermediaries are absent and firms self finance their activity.

This paper is only a first attempt to understand the interactions between firms dynamics, and in particular the dynamics of the exit margin and banking. We strongly believe that further investigation, both from a theoretical and an empirical point of view, is needed on this issue. In this respect, the model can be extended along several dimensions. First, con- 
sidering a different borrowing mechanism, where firms can borrow against a collateral, might be interesting to investigate. The estimation of the model through Bayesian techniques is also a future step of our research. Finally, investigating the role of firms endogenous exit in affecting welfare and the optimal monetary prescriptions is also part of our agenda.

\section{References}

Aliaga-Díaz, Roger \& Olivero, María Pía, (2012). Do Bank Capital Requirements Amplify Business Cycles? Bridging The Gap Between Theory And Empirics, Macroeconomic Dynamics, vol. 16(03), 358-395.

Angelini, Paolo, Cetorelli, Nicola, (2003). The Effects of Regulatory Reform on Competition in the Banking Industry, Journal of Money, Credit and Banking, Blackwell Publishing, vol. 35(5), 663-84.

Asea, Patrick K. and Brock Blomberg. (1998). Lending Cycles. Journal of Econometrics 83 (1-2):89-128.

Asturias Jose, Hur Sewon, Kehoe Timothy J., Ruhl Kim J., (2017). Firm Entry and Exit and Aggregate Growth, NBER Working Paper No. 23202.

Bartelsman, Eric, Haltiwanger, John and Scarpetta, Stefano. (2004) Microeconomic evidence of creative destruction in industrial and developing countries, Policy Research Working Paper Series 3464, The World Bank.

Basu Susanto, John G. Fernald and Miles S. Kimball. (2006). Are Technology Improvements Contractionary?, American Economic Review, vol. 96, pp. 14181448.

Bergin, Paul, Corsetti, Giancarlo, (2008). The external margin and monetary policy. Journal of Monetary Economics 55(7), 1222-1237.

Bergin Paul, Ling Feng, Ching-Yi Lin, (2014). Financial Frictions and Firm Dynamics, NBER Working Paper No. 20099.

Bilbiie Florin O. Fabio Ghironi and Marc J. Melitz, (2012). Endogenous Entry, Product Variety, and Business Cycles, Journal of Political Economy, University of Chicago Press, vol. 120(2), $304-345$.

Bilbiie Florin O. Fabio Ghironi and Ippei Fujiwara,(2014). Optimal Monetary Policy with Endogenous Entry and Product Variety, Journal of Monetary Economics, vol.(64), pp. 1-20.

Brand Thomas, Isoré Marlène and Fabien Trieper (2017), Uncertainty Shocks and Firm Dynamics: Search and Monitoring in the Credit Market, mimeo.

Broda, C., and D. E. Weinstein. 2010. Product Creation and Destruction: Evidence and Price Implications. The American Economic Review vol(100), pp. 
691-723.

Burnside, C., Eichenbaum, M. and Rebelo, S.: 1995, Capital utilisation and returns to scale, in B. Bernanke and J. Rotemberg (eds), NBER Macroeconomics Annual (MIT Press), Vol. 10, pp. 67-110.

Cacciatore, Matteo, Ghironi Fabio and Stebunovs Viktors, (2015), The Domestic and International Effects of Interstate U.S. Banking, Journal of International Economics, 95, 171-187.

Campbell, J. R., (1998). Entry, Exit, Embodied Technology, and Business Cycle. Review of Economic Dynamics; 1 (2); 371-408.

Cavallari, Lilia, (2013). Firms' entry, monetary policy and the international business cycle, Journal of International Economics, Elsevier, vol. 91(2), 263-274.

Cavallari, Lilia, (2015). Entry costs and the dynamics of business formation, Journal of Macroeconomics, Elsevier, vol. 44(C), pages 312-326.

Casares, Miguel, Poutineau, Jean-Christophe (2014). A DSGE model with endogenous entry and exit, mimeo

Chari, VV, Patrick Kehoe, and Ellen McGrattan. (2008). Are Structural VARs with Long Run Restrictions Useful in Developing Business Cycle Theory?, Journal of Monetary Economics 55(8), 1337-1352.

Chang, Y. and Hong, J. (2006). Do technological improvements in the manufacturing sector raise or lower employment?, American Economic Review 96, $352-368$.

Christiano Lawrence J., Martin Eichenbaum and Charles L. Evans. Source: Journal of Political Economy, Vol. 113(1), pp. 1-45.

Christiano, Lawrence J, Martin Eichenbaum, and Robert Vigfusson. (2006). Alternative Procedure for Estimation Vector Autoregressions Identified with Long Run Restrictions. Journal of the European Economic Association 4(2), 475-483.

Clementi Gian Luca, Palazzo Berardino. (2016), Entry, Exit, Firm Dynamics, and Aggregate Fluctuations, American Economic Journal: Macroeconomics, 8(3): $1-41$.

Colciago, Andrea, Rossi, Lorenza, (2015a). Firms Entry, Oligopolistic Competition and Labor Market Dynamics, De Nederlandsche Bank Working Paper No. 465.

Colciago, Andrea, Rossi, Lorenza, (2015b). Firm Entry, endogenous markups and the dynamics of the labor share of income, Macroeconomic Dynamics, 2015, 19 (6), 1309-1331.

Colciago, Andrea, Endogenous Market Structures and Optimal Taxation, The Economic Journal, 2016, 26 (594), 1441-1483.

Curdia, Vasco, Woodford, Michael, (2009). Credit Frictions and Optimal 
Monetary Policy, BIS Working Papers n. 278.

Dixit, A. K. and J. E. Stiglitz (1977). Monopolistic competition and optimum product diversity. American Economic Review, 67 (3), 297-308.

Dueker Michael J., Daniel L. Thornton, (1997), Do Bank Loan Rates Exhibit a Countercyclical Mark-up?, Working Paper 1997-004A, Federal Reserve Bank of ST. Louis.

Epstein Brendal, Shapiro Alan Finkelstein, (2017), Banking and Financial Participation Reforms, Labor Markets, and Financial Shocks, mimeo

Etro Federico, Colciago Andrea, (2010). Endogenous Market Structures and the Business Cycle, The Economic Journal, Royal Economic Society, vol. 120(549), 1201-1233.

Fernandez-Villaverde, J., Guerron-Quintana, P., Rubio-Ramirez, J. F., and Uribe, M. (2011). Risk matters: The real effects of volatility shocks. American Economic Review, 101(6):2530-61

Gerali A., S. Neri, L. Sessa and F. M. Signoretti, (2010) Credit and banking in a DSGE model of the euro area, Journal of Money, Credit and Banking, 42(1), 107-141.

Ghironi, Fabio, Melitz, Mark. J., (2005). International Trade and Macroeconomic Dynamics with Heterogeneous Firms. Quarterly Journal of Economics; 120(3), 865-915.

Ghironi, Fabio, Melitz, Mark. J., (2007).Trade Flow Dynamics with Heterogeneous Firms, American Economic Review ,97 (AER Papers and Proceedings): 356-361.

Hamano, Masashige, Zanetti, Francesco (2015). Endogenous Establishment Destruction and Macroeconomic Dynamics,Economics Series Working Papers 759, University of Oxford, Department of Economics.

Hannan T.H. and Berger, A.N, (1991). The Rigidity of Prices: Evidence from the Banking Industry, American Economic Review, vol. 81(4), 938-45.

Jaimovich, N., Floetotto, M., (2008). Firm Dynamics, Mark-up Variations and the Business Cycle. Journal of Monetary Economics; 55 (7); 1238-1252.

Kwan, H. Simon, (2010). Financial Crisis and Bank Lending, Working Paper Series 2010-11, Federal Reserve Bank of San Francisco.

La Croce Carla, Lorenza Rossi, (2014), Endogenous Entry, Banking, and Business Cycle, DEM Working Papers Series 72, University of Pavia, Department of Economics and Management.

Lee, Y., and T. Mukoyama. 2015. Entry, Exit, and Plant-Level Dynamics over the Business Cycle. European Economic Review, vol. 77(C), pp. 20-27

Lewis, Vivien and Poilly, Céline, (2012). Firm entry, markups and the mon- 
etary transmission mechanism, Journal of Monetary Economics, Elsevier, vol. 59(7),670-685.

Lewis, Vivien, Business Cycle Evidence on Firm Entry, 2009, Macroeconomic Dynamics, 13(5), 605-624.

Lewis, Vivien and Stevens Arnoud, Entry and Markup Dynamics in an Estimated Business Cycle Model, 2015, European Economic Review, 74, 14-35.

Lown, Cara S. and Donald P. Morgan. 2006. The Credit Cycle and the Business Cycle: New Findings Using the Loan Officer Opinion Survey. Journal of Money, Credit and Banking 38 (6):1575-1597.

Melitz, M.J., (2003). The Impact of Trade on Intra-Industry Reallocations and Aggregate Industry Productivity. Econometrica; 71(6), 1695-1725.

Nikitin Maxim, Smith R. Todd, (2009). Bank Spreads and Business Cycles, Manuscript, University of Alberta.

Olivero, María Pía, 2010. Market power in banking, countercyclical margins and the international transmission of business cycles, Journal of International Economics, Elsevier, vol. 80(2), 292-301.

Rotemberg, Julio, (1982). Monopolistic Price Adjustment and Aggregate Output, Review of Economic Studies, 49, 4, 517-31.

Rousseas, S. (1985) A markup theory of bank loan rate. Journal of Post Keynesian Economics, 8(1), 135-144.

Shao Enchuan and Pedro Silos, (2014). Accounting For The Cyclical Dynamics Of Income Shares, Economic Inquiry, vol. 52(2), pages 778-795.

Shao, Enchuan \& Silos, Pedro, (2013). Entry costs and labor market dynamics, European Economic Review, vol. 63(C), pages 243-255.

Sims, C. A. and Zha, T. (1998). Bayesian methods for dynamic multivariate models. International Economic Review, 39(4):949-68.

Smets, Frank, and Rafael Wouters. (2007). Shocks and Frictions in US Business Cycles: A Bayesian DSGE Approach. American Economic Review, 97(3): 586-606.

Totzek, Alexander (2009). Firms' Heterogeneity, Endogenous Entry, and Exit Decisions. Economics Working Paper 2009-11. Department of Economics, Christian-Albrechts Universitaet, Kiel.

Vilmi Lauri, (2011), The Effects of Endogenous Firm Exit on Business Cycle Dynamics and Optimal Fiscal Policy, Sveriges Riksbank, Working Paper Series 250.

WuJing Cynthia and Xia Fan Dora, (2016), Measuring the Macroeconomic Impact of Monetary Policy at the Zero Lower Bound, Journal of Money, Credit, and Banking, 48(2-3), 253-291. 


\section{Appendix}

Figure 1A shows the IRFs obtained using the utility adjusted TFP under Minnesota Priors.
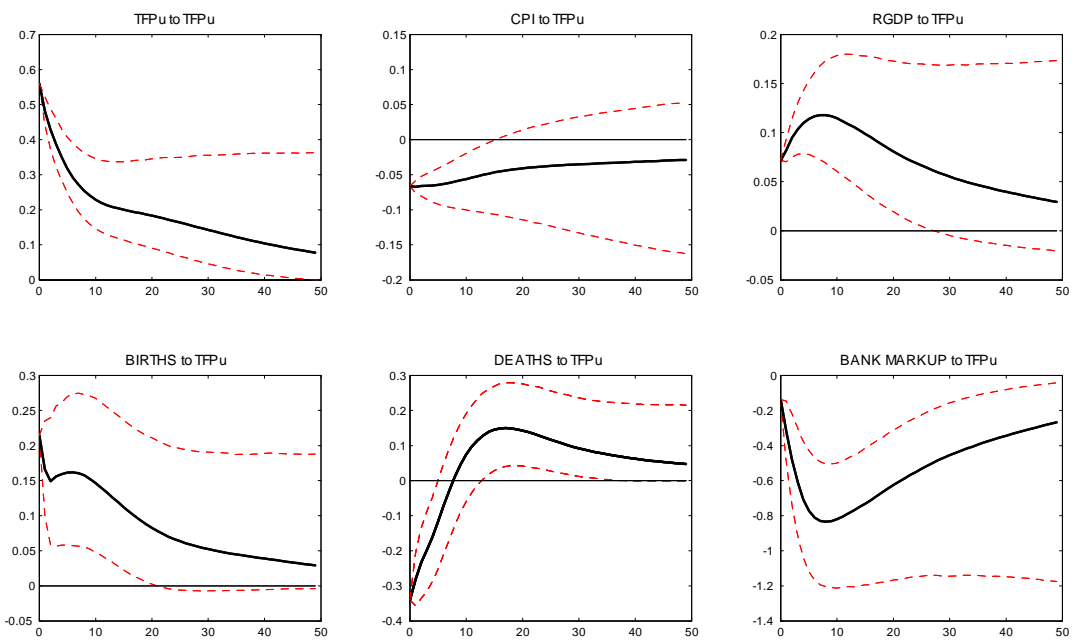

Figure 1A. IRFs to a 1 standard deviation TFP shock. Minnesota Priors

Figure 2A-3A show the IRFs to a positive shock to labor productivity and to utility adjusted TFP, with Normal Diffuse priors. Notice that, the previous result are confirmed and that also the credible bands do not differ much from the ones obtained with Minnesota priors. 

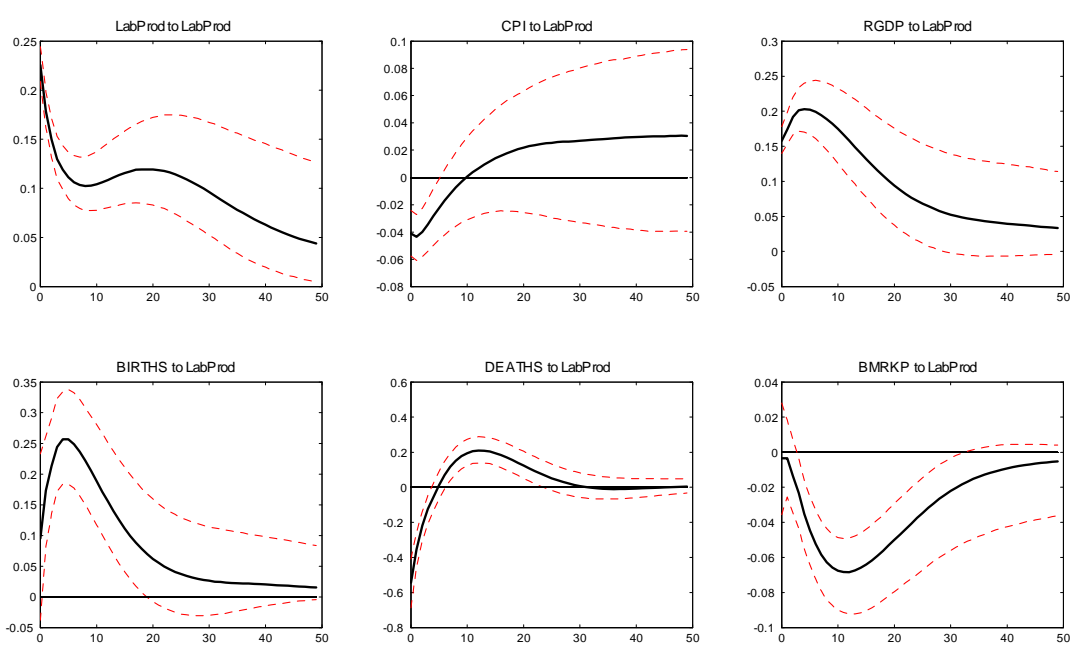

Figure $2 \mathrm{~A}$. IRFs to a 1 standard deviation labor productivity shock. Normal-Diffuse Priors
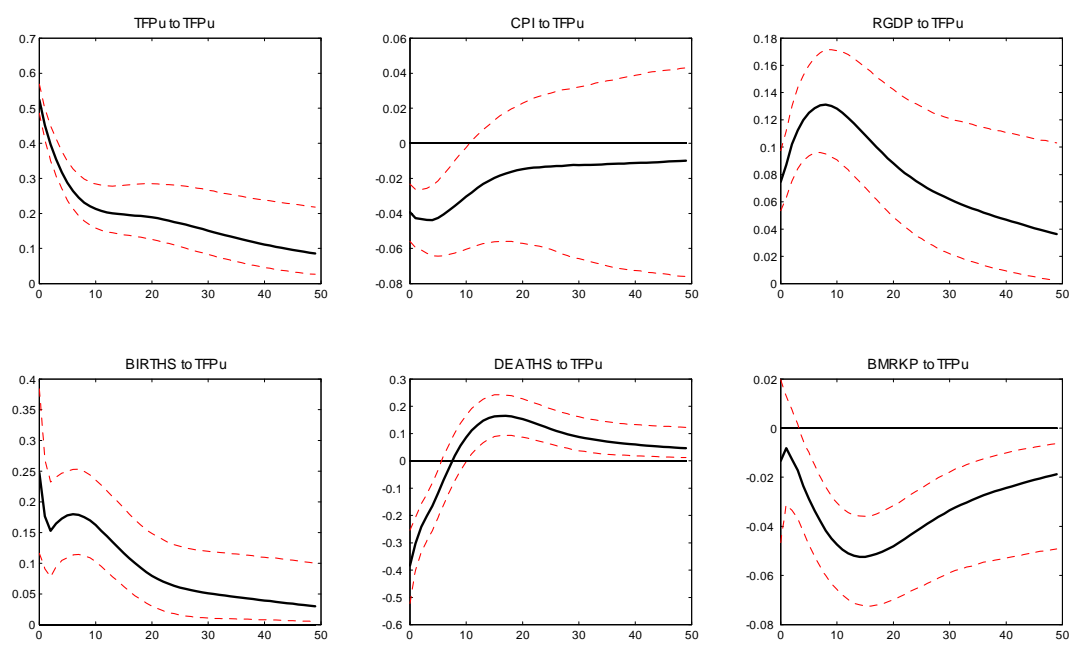

Figure 3A. IRFs to a 1 standard deviation TFP shock. Normal-Diffuse Priors

Finally, Figure $4 \mathrm{~A}$ and $5 \mathrm{~A}$ show the IRFs obtained using the two alternative proxies of the Bank Markup. 

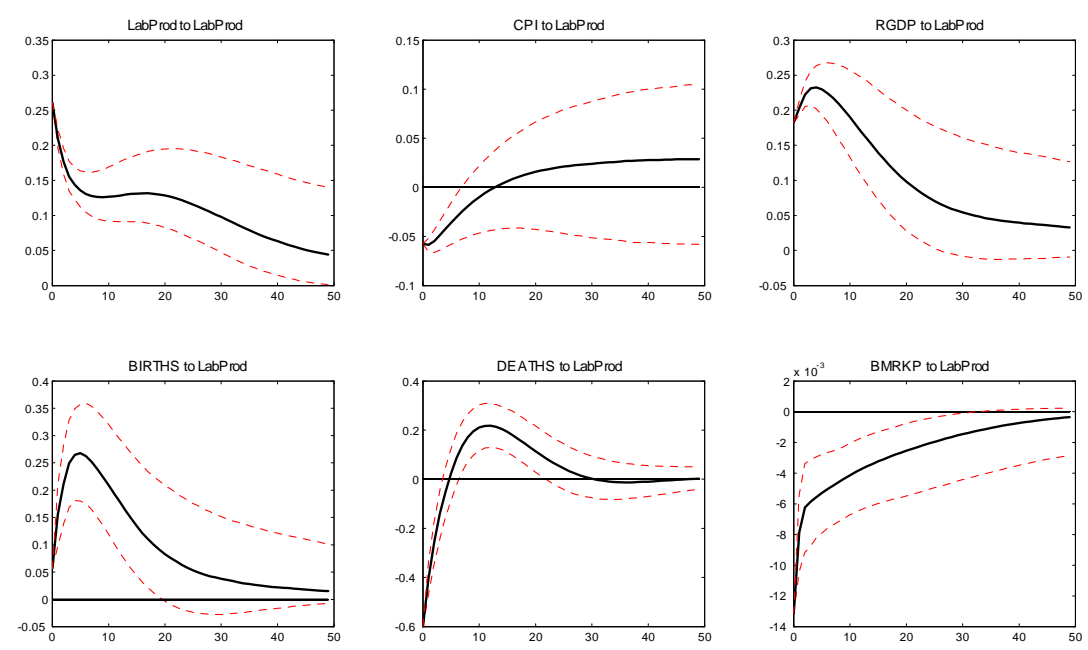

Figure 4A. IRFs to a 1 standard deviation productivity shock. Bank Markup: spread between the Loan Primce Rate and the EFFR.
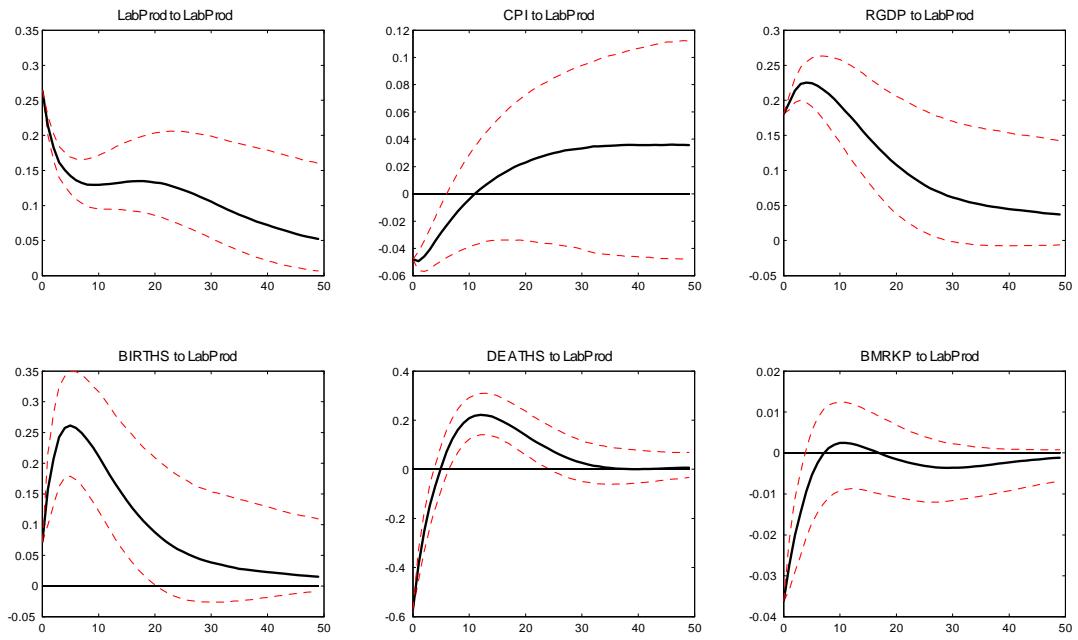

Figure 5A. IRFs to a 1 standard deviation productivity shock. Bank Markup: spread between the Loan Primce Rate and the TMTBR. 